\title{
DEVELOPMENT AND TESTING OF DATA REDUCTION SOFTWARE FOR MEASUREMENTS USING PRESSURE SENSITIVE PAINTS
}

\author{
William J. Deitrick*, Wit Stryczniewicz** \\ * The Ohio State University 201 W 19th Ave,Columbus, OH, United States \\ ** Aerodynamics Department, Institute of Aviation, Krakowska 110/114, 02-256 Warsaw, Poland \\ deitrick.15@osu.edu,wit.stryczniewicz@ilot.edu.pl
}

\begin{abstract}
The paper concentrates on post-processing of data necessary for pressure measurements using Pressure Sensitive Paints (PSP). The purpose of the study was to develop and test procedures for extraction of the surface pressure distribution from the images captured during PSP tests. The core issues addressed were reduction of the influence of model movement and deformation during wind tunnel run and synchronization between conventional pressure tap measurements and PSP data, necessary for in-situ calibration. In the course of the studies, two approaches on image registration were proposed: the first based on geometric transformation of control points pairs with cross-correlation tuning and the second based on similarity finding and estimation of geometric transformation of the images. Performance of the developed algorithm was tested with use of experimental set-up allowing for controlled movement of the imagined target with micrometer resolution. Both of the proposed approaches to PSP image resection proved to perform well. After testing of the software, the PSP system was used for determination of the pressure field on flat plate exposed to impinging jet. The presented procedures and results can be useful for research groups developing in-house PSP measurements systems for wind tunnel tests and internal flow investigations.
\end{abstract}

Keywords: Pressure Sensitive Paint, image registration, impinging jet

\section{INTRODUCTION}

In recent years, luminescent coatings have been developed as an efficient method of pressure [1] and temperature [2][3] measurement in wind tunnel tests. The Pressure Sensitive Paints (PSP) technique allows measurement of a surface pressure distribution on a model without the use of pressure taps. Currently, the PSP technique has been used by increasing number of research groups especially for low and high frequency pressure measurements of high speed and unsteady aerodynamic phenomena investigations [4-6]. The measurement is based on acquiring images of a paint which luminescence 
is a function of pressure under proper illumination conditions. The PSP system typically consists of a scientific grade camera, light source and pressure sensitive paint. Since optical measurements do not require interference and modifications of the model, implementation of PSP technique can bring considerable reduction of wind tunnel tests preparation time and costs. Additionally, application of pressure sensitive coatings provide surface pressure distribution, substantially exceeding the capabilities of classical pressure taps in terms of data quantity acquired in a single experiment. Nevertheless, implementation of PSP technique in a research facility requires considerable expenditures of resources, either for development of an in house PSP system or buying a commercial system, as well as training.

The Pressure Sensitive Paint is composed of active oxygen sensors and non-active components called binders. The active particles - luminophores, are quenched by oxygen molecules. The luminophores inside the paint are excited to a higher energy state by photon absorption. Oxygen then quenches the luminophores, causing a decrease in the intensity of light emitted by the paint. The decrease in luminescence is proportional to the concentration of oxygen which directly translates to the pressure. This relationship is described by the Stern-Volmer relations:

$$
\frac{I_{\text {ref }}}{I}=A(T)+B(T) \frac{P}{P_{\text {ref }}}
$$

where $\mathrm{I}_{\text {ref }}$ and I are the intensities of the paint at reference pressure and at the measurement conditions respectively, and $\mathrm{A}$ and $\mathrm{B}$ are both temperature dependent constants [7].

There are two methods of measuring pressure using PSP, intensity and lifetime. The intensity method is based directly on the Stern-Volmer relationship. The ratio of intensities of the photoluminescence of the paint is used to determine the surface pressure distribution. Typically, two images are acquired: first before the test (wind-off) and second during the wind tunnel test (wind-on). This causes a few measurement issues, among which the most prominent are model movement and stability of the light source during the test [8]. The lifetime method is based on shorter paint emission decay time caused by the oxygen quenching. This method requires image acquisition only at the time of the wind tunnel run. The lifetime method requires more sophisticated hardware but avoids many of the issues associated with the intensity method.

Although, the lifetime method is currently considered as more promising, especially for unsteady measurements [9] the intensity method is favourable for first time implementation of PSP in research facilities and pilot tests. The following experiments were conducted to prepare a tool to post process images using the intensity method. The Aerodynamic Department of the Institute of Aviation (IoA) in Warsaw recently started implementing the use of PSP as an alternative method of calculating a pressure gradient on an object. This paper presents developed data reduction procedures and results of software testing.

\section{MATERIALS AND METHODS}

In the presented studies, image processing and a PSP in-situ calibration algorithm were developed and tested. Two approaches to the image resection were proposed. The first used a manual marker selection tool. The second used an algorithm to detect the similarities in the images to automatically find the markers. The performance of the developed algorithms were tested with use of images and pressure data acquired with use of camera and pressure scanners intended as elements of the PSP system. The developed system was used for determination of pressure distribution on a flat plate exposed to jet of air. 


\subsection{Data reduction}

The most importation aspect of the data reduction is to provide accurate result of the Iref/I operation. For that reason it is necessary for the images to be perfectly aligned. While testing in the wind tunnel, aerodynamic loads can displace and deform the model. To correct the model movement, wind on images have to be realigned using image registration. In order to provide favourable image processing conditions, similar points on the model have to be used. Typically, dark markers are painted on the surface of the model [8-12].

The manual selection uses a tool created to select the markers by clicking the points that match. The algorithm corrects the user's selections using cross-correlation. A $3 \times 3$ transformation matrix is created by the algorithm using the markers. This matrix is then used to transform the entire image.

The automatic selection first detects various points in each image using a processes called Speeded Up Robust Features (SURF) [13]. The algorithm then analysis both sets of features and determines the similar features. The images are then displayed with the markers shown asking the user if they were determined correctly. If the user selects yes, the algorithm performs a transformation identical to the manual selection with the markers found automatically. If the user is not satisfied, the manual selection process will be run.

A software was developed in-house to process the images after the experiment and provide surface pressure data. Fig. 1 is a flowchart that shows the steps the algorithm follows.

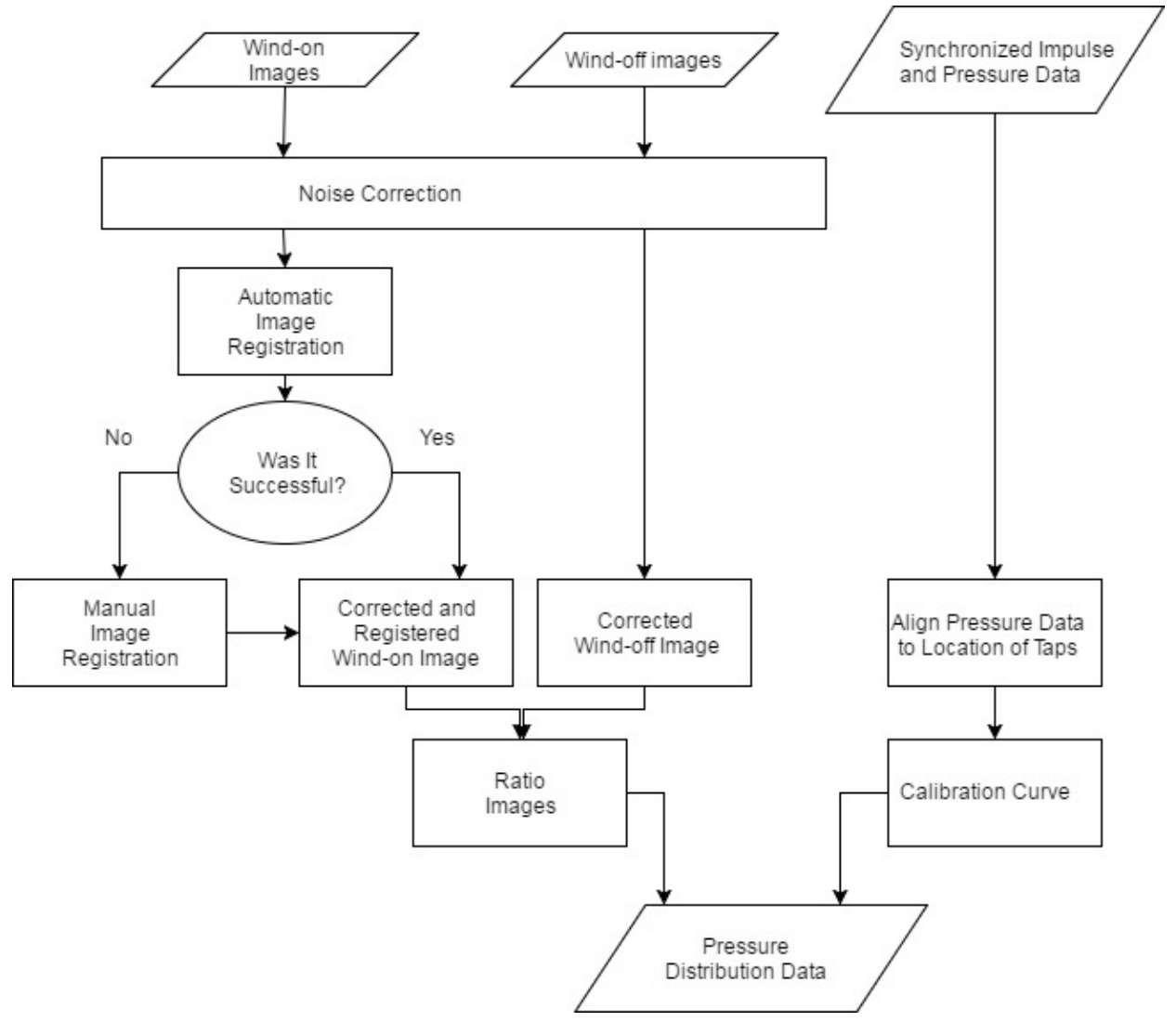

Fig. 1. Algorithm Flowchart. 
To calculate the pressure, the paint must be calibrated. By determining Iref/I at different pressures, a calibration curve can be created. There are two methods that can be used for calibration, a-priori and in-situ. The a-priori method uses a calibration chamber with a controlled internal pressure. Two advantages of using an a-priori method are that it can be done before any wind tunnel test, and it eliminates the need for any pressure taps on the model. However, a disadvantage of this method is the necessity of a controllable pressure chamber or alternately pressurised wind tunnel. The in-situ method uses traditional pressure taps during the experiment. The wind-on pressures are associated to the intensity ratio at the point of the tap. Pressure data must be synchronized with the camera to insure accurate calibration. The developed software includes functions to manually select the locations of the pressure taps. A user is prompted to select which pressure taps were chosen. The software loads the pressure data from the selected taps. Calibration curves can then be generated for each image.

\section{EXPERIMENTAL SET-UP}

The image resection test stand consisted of: a Dantec Dynamics calibration board with precisely placed dots used as the model, a ThorLabs MTS50/M-Z8 Motorized Translation Stage to translate the board, two Manfrotto tripods with precise tilt and rotation angle control, and a digital spirit level. This system allowed the researchers to simulate the movement and rotation of the model in range from micrometres to $50 \mathrm{~mm}$ and 0.1 degree accuracy respectively. The images were acquired with a scientific grade CCD camera PCO2000. The camera has a 4 Mega pixel cooled chip with 12 bit dynamic range. In order to provide stable illumination of the board, a HardSoft IL-106X pulsed LED illuminator [14] with a green LED was utilized. The marker size dependency was tested with use of two Cannon lenses, a $35 \mathrm{~mm}$ and $100 \mathrm{~mm}$, while keeping the same distance between the camera and the target.

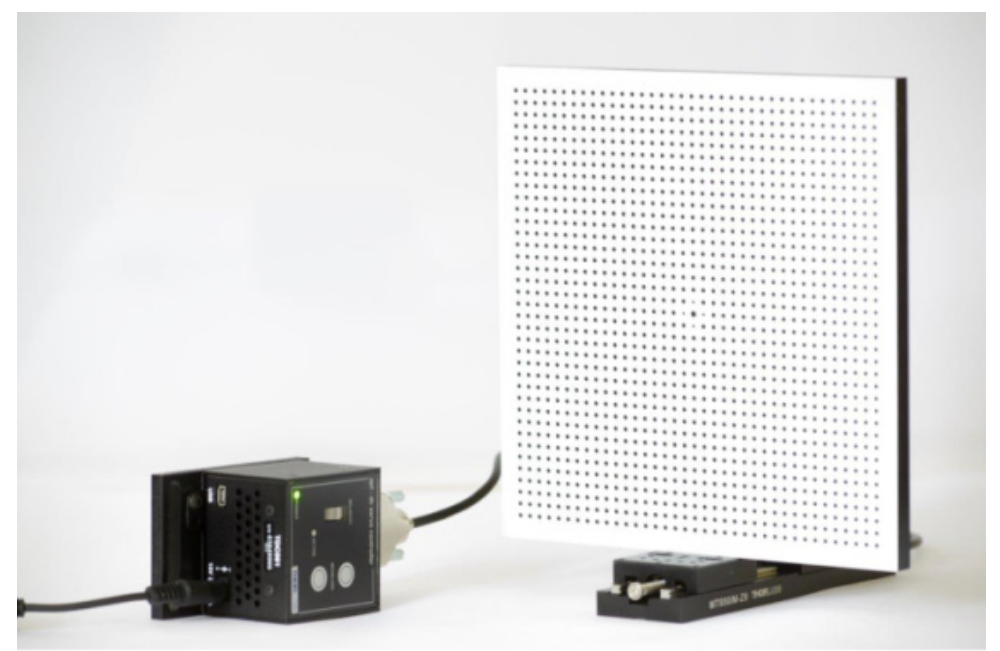

Fig. 2. View of the calibration board placed on a motorized translation stage 


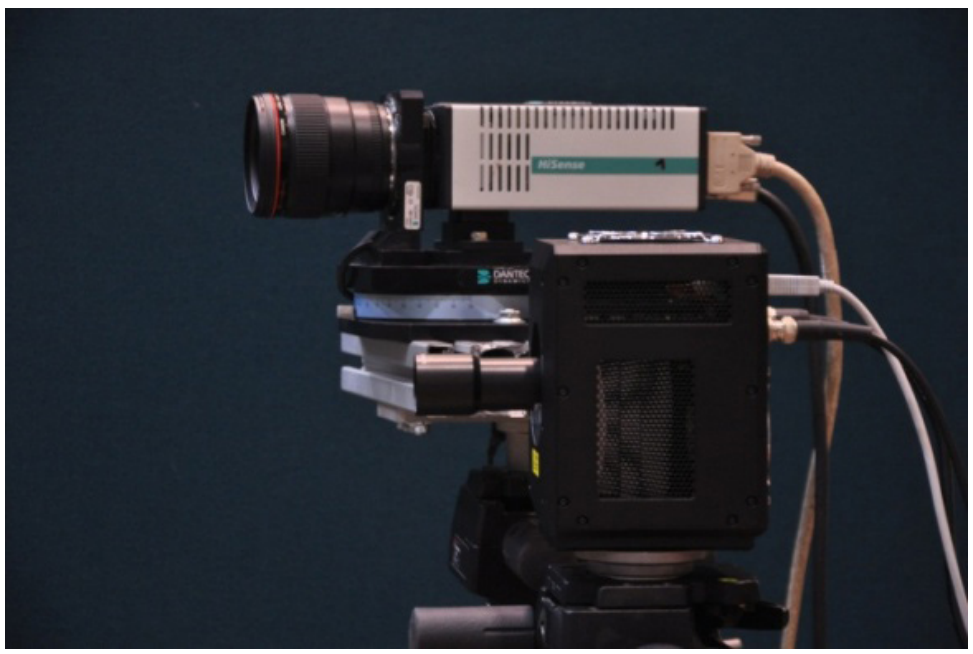

Fig. 3. View of camera and illuminator

The first experiment was conducted to determine whether the software would successfully align an image. For each lens, 13 positions were tested. The first image was taken in the 'HOME' position to represent the wind off image. Images were taken at six different translations 1, 10, 100, 1000, 10000 and $50000 \mu \mathrm{m}$. The board was then rotated by three times: $1^{\circ}, 2.5^{\circ}$ and $5^{\circ}$ from 0 . At each rotation, two images were taken, one at the 'HOME' location and one translated by $10 \mathrm{~mm}$.

The manual software's registration abilities were tested using the images captured. The error for the board was calculated and both sets of data were plotted together for comparison. The first markers chosen were the four corners and the center mark. After the initial results, different amounts and locations of markers were chosen.

Due to the large amount of markers on the calibration board, the automatic software could not distinguish between different markers and a second experiment was required. The test was conducted with the same camera and LED light source. A schematic of the airfoil to be tested with the PSP was printed and markers were painted on it. The first experiment determined the best place for the markers was in the corners and the center of the edges. Using this information, the markers were placed there on the schematic. The schematic was affixed to a board that could manually be translated horizontally and rotated. Translations were measured using a ruler and rotations were measured using the same digital protractor. During this experiment, the LED was also focused centrally on the image to help reduce the light gradient noticed from the results of the first experiment.

Four images were taken of the schematic. Initially an image was taken at a reference position. The schematic was then rotated $2.5^{\circ}$. Returning back to the reference position, the schematic was translated by $5 \mathrm{~mm}$ and $10 \mathrm{~mm}$. These images were tested using the automatic maker selection, as well as the manual selection. The error was computed for both and the values were compared. 

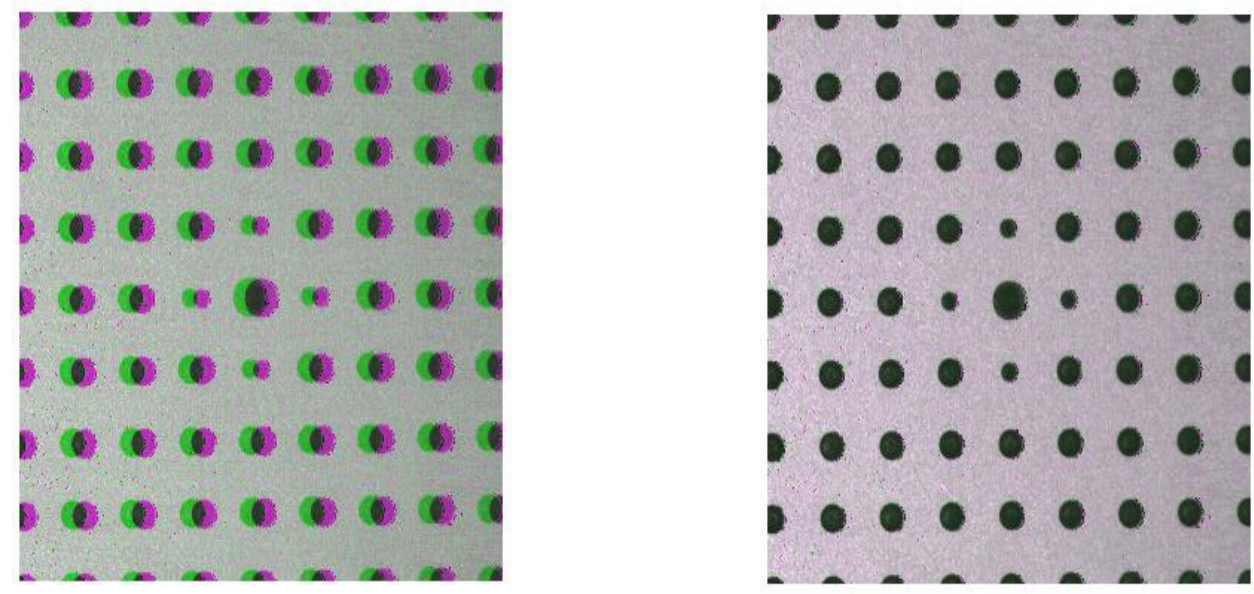

Fig. 4. (left) images before resection, (right) image resection using manual marker selection and $100 \mathrm{~mm}$ lens

A third test was conducted to test the capabilities of synchronizing pressure data with image time. Using the same camera as the previous tests, images were taken of a balloon being popped. The pressure was recorded with DTC Initium system. Pressure was read from an Initium ESP scanner directly under the balloon. A Dantec Dynamics Timer Box was used to send triggering impulses to the camera from the image acquisition computer. The BNC cable connecting the camera to the timer box was also connected to a National Instruments NI USB-6259 data collecting card to record the time of impulse. There were a total of 100 images captured at a rate of $10 \mathrm{~Hz}$ per image. Both the recording of camera triggering impulses and the pressure data collection were synchronized with the use of the PC internal clock.

The developed software was used for determination of pressure distribution on a flat plate exposed to impinging jet of air. The binary-FIBTM pressure sensitive paint, provided by ISSI company, was used. The paint has good sensitivity on pressure and very low on temperature changes, this feature makes it well suitable to wind tunnel testing. The parameters of the paint are presented in Table 1.

Table 1. binary-FIBTM PSP data []

\begin{tabular}{|l|c|}
\hline Pressure sensitivity & $0.6 \%$ per $\mathrm{kPa}$ \\
\hline Pressure range & \\
& $0-\mathrm{kPa}$ to $200-\mathrm{kPa}$ \\
\hline Temperature sensitivity & $0.03 \%$ per ${ }^{\circ} \mathrm{C}$ \\
\hline Temperature range & $0^{\circ} \mathrm{C}$ to $50^{\circ} \mathrm{C}$ \\
\hline Response time & $300 \mathrm{~ms}$ \\
\hline
\end{tabular}

The paint was excited with HardSoft IL-106X pulsed LED illuminator [9] with UV LED. The maximum of emission of the illuminator was $405 \mathrm{~nm}$, which is optimal for paint used. Maximum emission intensity of pressure sensors in the paint has a pick equal to $550 \mathrm{~nm}$. Therefore, in order to reduce SNR level an optical high pass filter $(510 \mathrm{~nm})$ was mounted on $35 \mathrm{~mm}$ lenses of the PCO2000 camera used in the PSP system. The nozzle for jet creation was placed above a row of pressure taps 
on the flat plate. The pressurized air was provided form compressor. The pressures from the taps was acquired using a DTC Initium system. The pressure data was used for in-situ calibration of the PSP measurement data. A scheme of the experimental set-up in presented in Fig. 5. The measurement was made in a darkroom so there was no influence of external light.

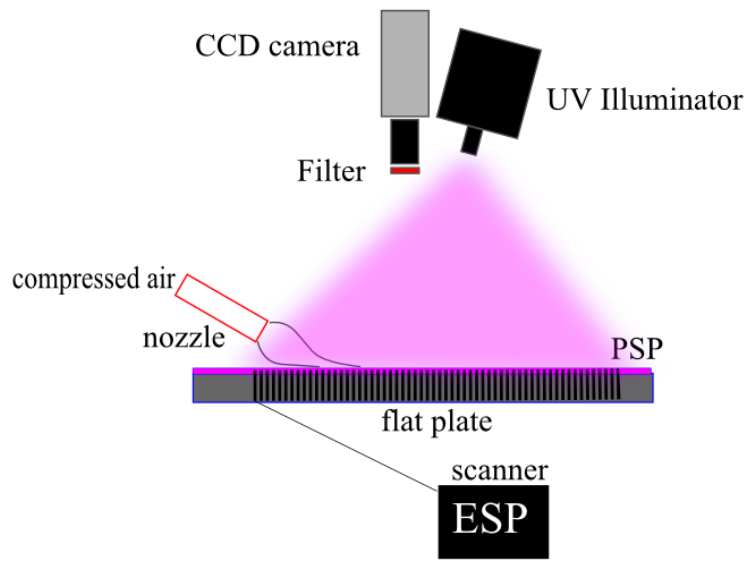

Fig. 5. Impinging jet experimental setup

\section{RESULTS}

The results of the experiments were consistent with each lens. Fig. 6 shows the translations from $1 \mu \mathrm{m}$ to $1 \mathrm{~mm}$ had very similar errors. Any translation over $1 \mathrm{~mm}$, however, had much larger error associated with it. There was a fairly large light gradient on the board, causing the images to not be perfectly similar.

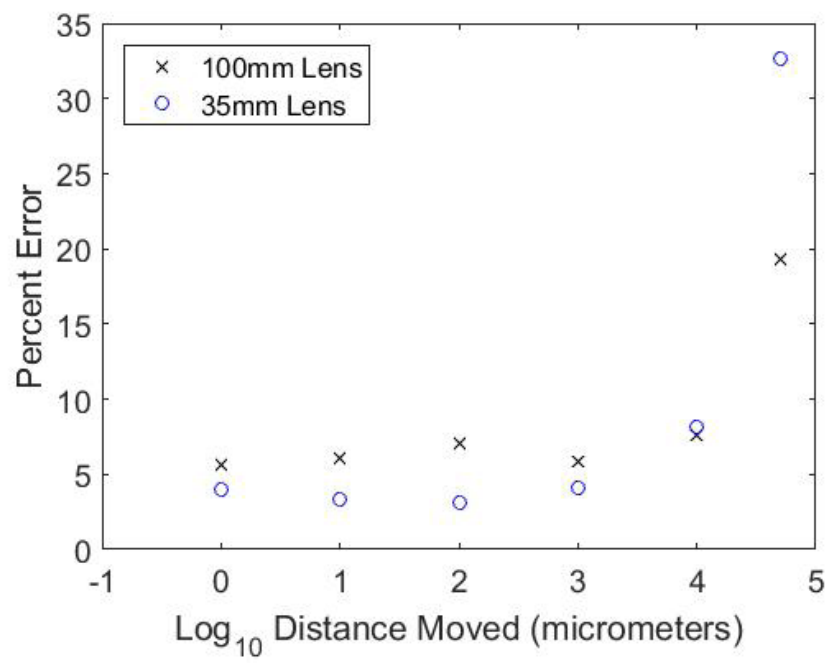

Fig. 6. Percent Error vs Distance Translated 
It was also observed there was less error when using the $35 \mathrm{~mm}$ lens (see Fig. 5). In the manual approach. When selecting a marker, it is necessary to select the same place on both images. Using the $100 \mathrm{~mm}$ lens, the marker width was 16 pixels, and 5 pixels with the $35 \mathrm{~mm}$. The smaller markers made it easier to precisely select the same point.

The plots for the images that were rotated are presented in Fig. 7 and Fig. 8. Again it was observed that the $35 \mathrm{~mm}$ lens produced a better image registration. The angle of rotation during the translation was also calculated. For both the 35 and $100 \mathrm{~mm}$ lenses, the images were rotated all within 0.05 degrees of the physical rotation. Doing so helped determine that the light gradient was a large source of the error.

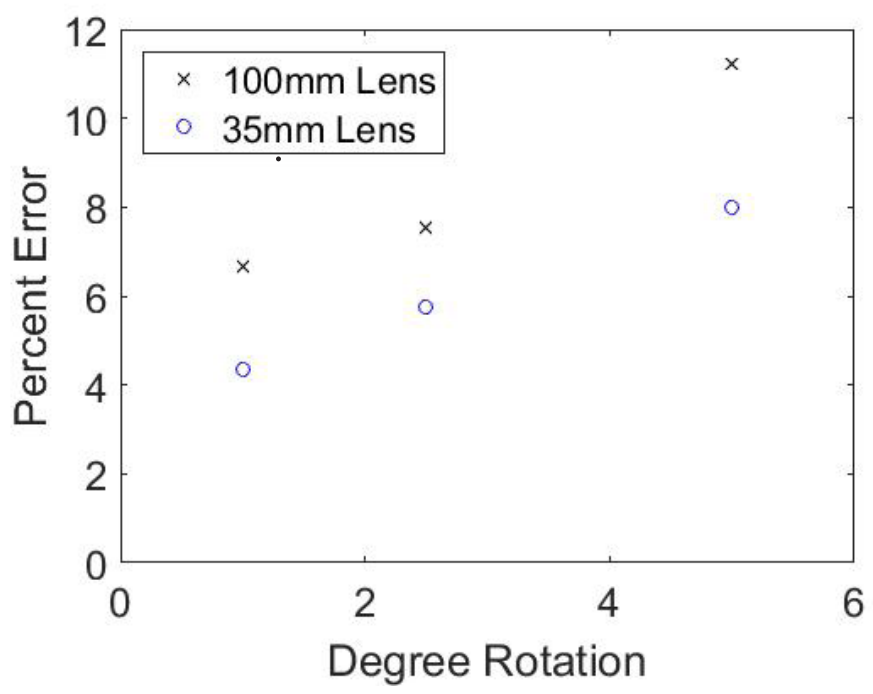

Fig. 7. Percent Error vs Degree Rotation without any Translation

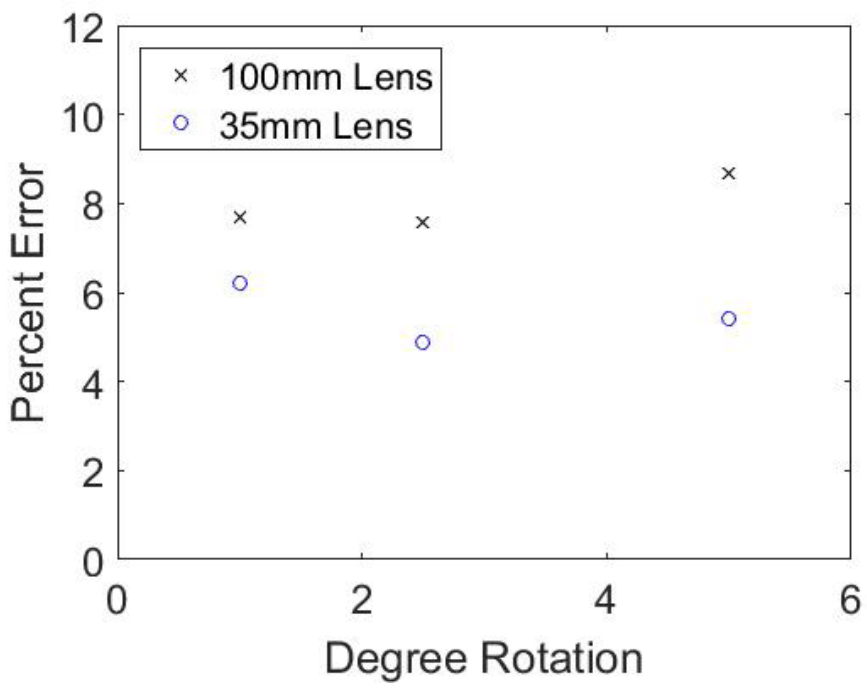

Fig. 8. Percent Error vs Degree Rotation with $10 \mathrm{~mm}$ Translation 
It can be observed from Table 1 that the number of markers did not change the accuracy of the resection. Along with testing the number of markers, the software was also tested by selecting markers in the centre of the board, instead of on the outside corners. This led to a resection that aligned the centre of the image, but the outside edges were distorted. It was concluded that markers were needed on the outside edges of the object being tested.

Table 2. Changes in error when more markers are used

\begin{tabular}{|l|c|c|c|c|c|c|}
\hline Number of Markers & 5 & 6 & 7 & 8 & 9 & 10 \\
\hline & \multicolumn{7}{|c|}{ Error [\%] } \\
\hline $100 \mathrm{~mm}$ Lens & 7.79 & 7.77 & 7.74 & 8.19 & 7.79 & 8.19 \\
\hline $35 \mathrm{~mm}$ Lens & 2.66 & 2.66 & 2.66 & 2.66 & 2.66 & 2.63 \\
\hline
\end{tabular}

The automatic selection software successfully located a majority of the markers. The software was run five times for each image, and the automatic selection software resectioned the images in the same way every time. The manual selection tool received user error when markers were not selected exactly on the same pixel for the five runs. The data was averaged and are presented in Table 2. While the images that were rotated $2.5^{\circ}$ were successfully resectioned by the software, the light gradient was too large and created error in the $20 \%$ region for both automatic and manual.

Table 3. Performance of automatic and manual algorithm

\begin{tabular}{|l|l|l|}
\hline Distance of translation & $5 \mathrm{~mm}$ & $6 \mathrm{~mm}$ \\
\hline Automatic procedure error [\%] & 1.83 & 2.08 \\
\hline Manual procedure error [\%] & 2.07 & 2.09 \\
\hline
\end{tabular}

The results provide a baseline for how makers should be placed to the highest degree of software accuracy. It was determined that the markers should be placed in large spacing for example in corners of the image. Also noticed was the impact of marker size on the accuracy of the image registration. That observation aligns with the observations made by Le Sant, who found that a marker should be between 3 and 10 pixels in diameter [11]. The results of the synchronisation test are presented in Fig. 9. The software created for post processing found the pressure at the instant the impulse from the timer box was sent. As illustrated in Fig. 9, the pressure at each impulse was plotted along with the impulse to determine if they occurred at the same time. The results of the test was used to verify the procedures for correlating the PSP images with data from the pressure taps used in in-situ calibration.

After testing of the individual components of the PSP system the pressure measurements was performed. The pressure distribution below a nozzle is presented in Fig. 10. Comparison between the PSP measurements and pressure taps is presented in Fig. 11. 


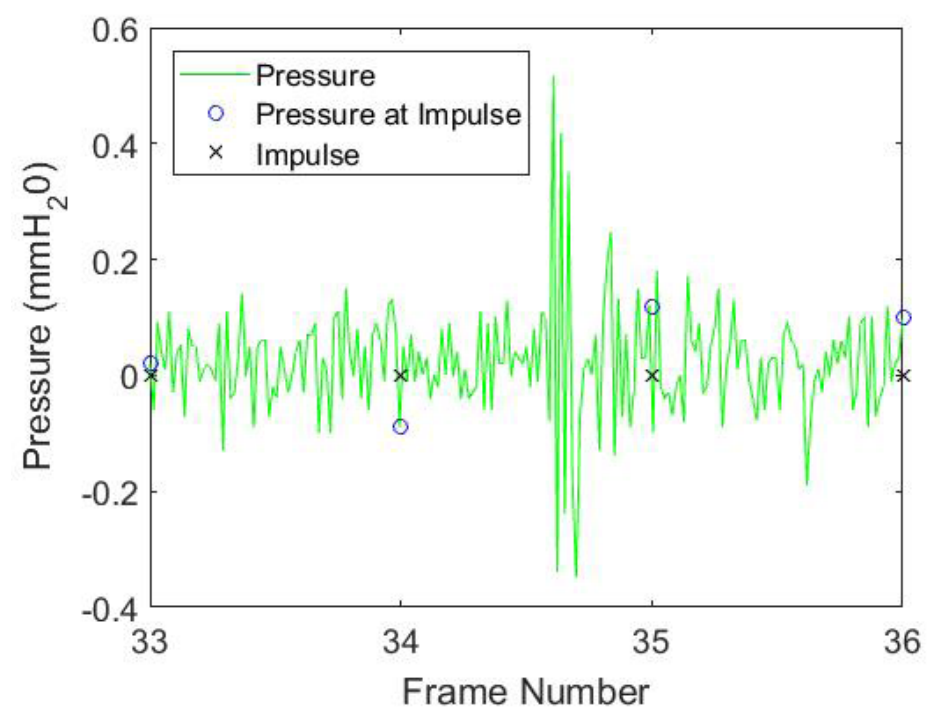

Fig. 9. Pressure vs Frame number

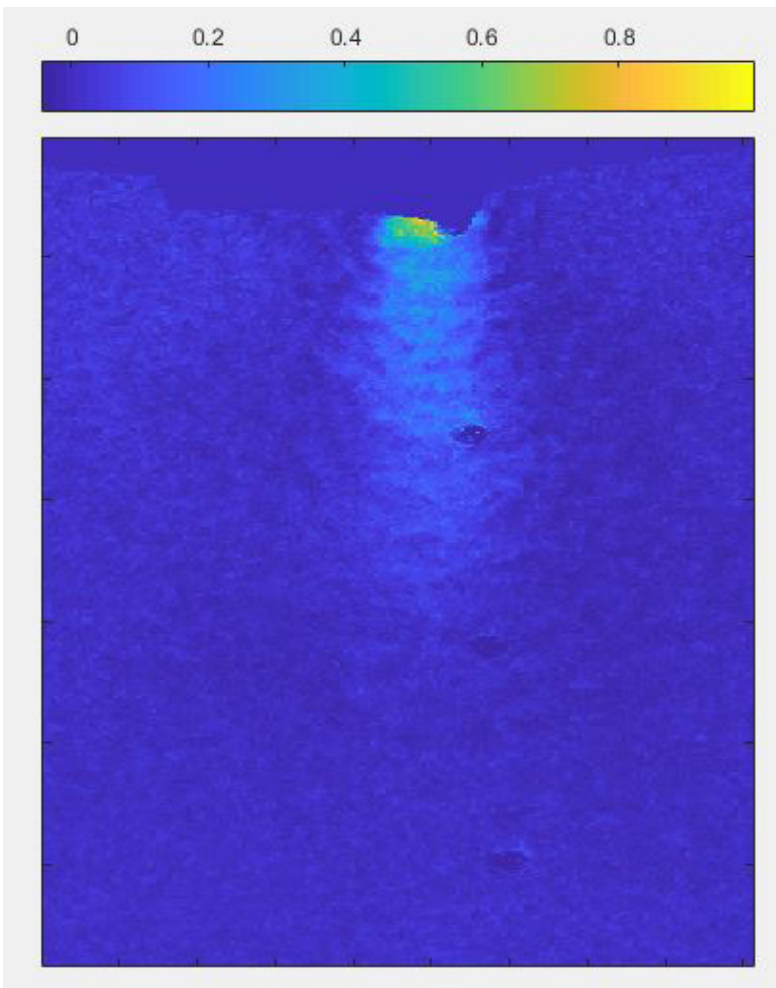

Fig. 10. Pressure distribution on a flat plate exposed to impinging jest of air. Colorbar represents the pressure in bars. The pressure taps can be seen as black dots. 


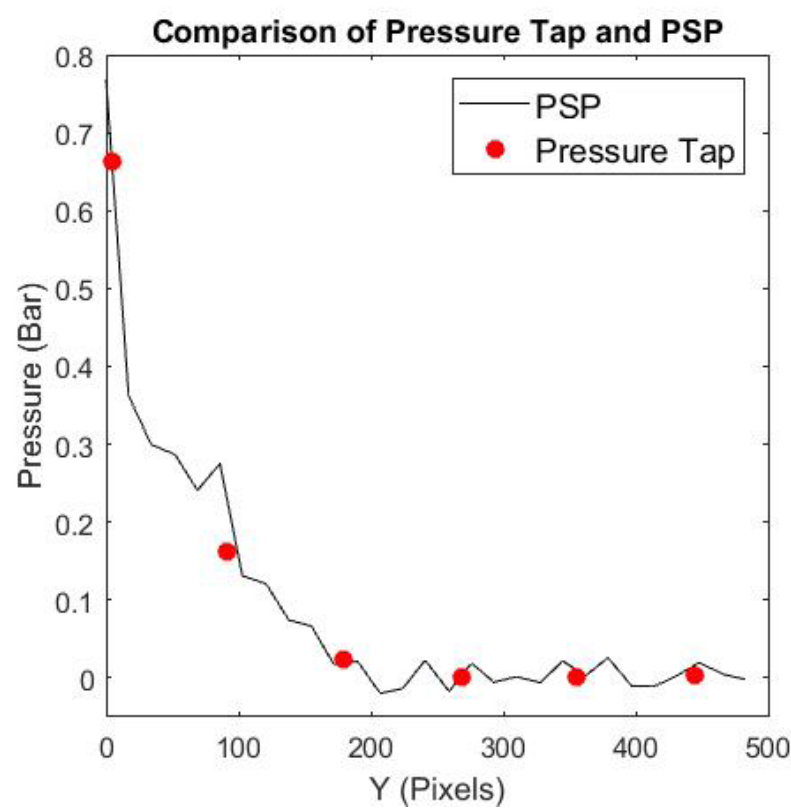

Fig. 11. Pressure distribution on flat plate exposed to air jet, measured with PSP

\section{CONCLUSIONS}

The experiments showed positive results for the software created. The automatic selection will be used in PSP tests, but the manual selection tool can be used if necessary. In wind tunnel testing, it is expected a model will only move in the range of millimetres. The proposed procedures has shown to successfully resection in this range. Additionally, recommendations for marker size, placement and number were formulated. Having perfectly synchronized pressure data with the cameras allows the use of in-situ calibration to be as accurate as possible. Both of the proposed approaches to PSP image resection proved to perform well in the test conditions with similar degrees of accuracy. Nevertheless, for PSP images taken during wind tunnel tests, the authors suggest a combined approach allowing manual markers selection in instances where the automatic procedures do not provide accurate results. After being extensively tested, the software was used to post process PSP results. The pressure distribution was determined and validated with complimentary measurements. The developed system can be used in for determination of the pressure distribution on models in wind tunnel tests and for internal flow investigations.

\section{BIBLIOGRAPHY}

[1] Klein C., Engler R., Henne U., 2005, "Application of pressure sensitive paint for determination of the pressure field and calculation of forces and moments of models in a wind tunnel", Experiments in Fluids, 39, pp. 475-485.

[2] Watkins A.N., Buck G.M., Leighty B.D., Lipford W.E., Oglesby D.M., 2008, "Using Pressureand Temperature-Sensitive Paint for Global Surface Pressure and Temperature Measurements on the Aft-Body of a Capsule Reentry Vehicle", 46th AIAA Aerospace Sciences Meeting and Exhibit, AIAA Paper-2008-1230, Reno, NV; United States, January. 
[3] Stryczniewicz W., Panas A.J., Szczepaniak R., 2018, “Thermophysical Properties of Temperature Sensitive Paint", 2018 Joint Thermophysics and Heat Transfer Conference, AIAA AVIATION Forum, Atlanta, United States, 25.-29. June.

[4] Gregory J.W., Asai K., Kameda M., Liu T., Sullivan J.P., 2008, "A review of pressure-sensitive paint for high-speed and unsteady aerodynamics", Proceedings of the Institution of Mechanical Engineers, Part G: Journal of Aerospace Engineering, Part G: Journal of Aerospace Engineering, 222, pp. 249-290.

[5] Crafton J., Forlines A., Palluconi S., Hsu K.Y., Carter C., Gruber M., 2015, "Investigation of transverse jet injections in a supersonic crossflow using fast-responding pressure-sensitive paint", Experiments in Fluids, 56:27.

[6] Peng, D., Wang, S., \& Liu, Y. (2016). Fast PSP measurements of wall-pressure fluctuation in low-speed flows: improvements using proper orthogonal decomposition. Experiments in Fluids, 57(4), 1-17. https://doi.org/10.1007/s00348-016-2130-z

[7] Kavandi J., Callis J., Gouterman M., Khalil G., Green E., Burns D., McLachlan B., 1990, "Luminescent barometry in wind tunnels. Review of Scientific Instruments", 61, pp. 3340-3347.

[8] Bell J. and McLachlan B., 1996, "Image registration for pressure-sensitive paint applications", Experiments in Fluids, 22, pp. 78-86.

[9] Disotell K., Peng D., Juliano T., Gregory J., Crafton J., Komerath N., 2014, "Single-Shot temperature and pressure-sensitive paint measurements on an unsteady helicopter blade", Experiments in Fluids, 55, pp. 1671.

[10] Le Sant Y. and Mérriene M.C., 2005, "Surface pressure measurements using pressure sensitive paint", Aerospace Science and Technology, 9, pp. 285-299.

[11] Le Sant Y., 2000, "Image processing tools applied to wind tunnel testing", In Proceedings of the 48th Annual CASI Conference, Toronto.

[12] Liu T. and Sullivan J.P., "Pressure and temperature sensitive paints", Springer-Verlag, 2005.

[13] Bay H., Tuytelaars T., Van Gool L., 2006, "SURF: speeded up robust features”, In H. Bischof, A. Pinz, editors, Computer Vision-ECCV 2006. Lecture Notes in Computer Science 3951, Springer.

[14] Stasicki B., Kompenhans J. , Willert C., Ludwikowski K., 2010, "Pulsed LED illuminator for visulization, recording and measurement of high-speed events in mechanics", In Proceedings of The Int. Conf. On Experimental Mechanics 2010, Kaula Lumpur, Malaysia.

\section{OPRACOWANIE ORAZ TESTY ALGORYTMU PRZETWARZANIA DANYCH POMIAROWYCH UZYSKANYCH TECHNIKĄ FARB CZUŁYCH NA CIŚNIENIE}

\section{Streszczenie}

W artykule przedstawiono procedury konieczne i wystarczajace do przeprowadzenia pomiarów techniką farb czułych na ciśnienie. Celem pracy było opracowanie oraz sprawdzenie procedur wyznaczenia rozkładu ciśnienia na powierzchni ze zdjęć pomiarowych farb czułych na ciśnienie. Głównymi 
podjętymi tematami była redukcja wpływu przemieszczenia i deformacji modelu podczas dmuchu w tunelu aerodynamicznym oraz synchronizacja pomiędzy pomiarem ciśnienia a rejestracją zdjęć. W pracy zaproponowano dwie metody uzgodnienia pozycji modelu pomiędzy zdjęciami: pierwsza metoda oparta na transformacji geometrycznej punków kontrolnych z dodatkowym uzgodnieniem wykorzystującym korelację obrazów znaczników oraz drugą metodę opartą na odnajdywaniu podobnych cech obrazów i estymacji przekształcenia geometrycznego obrazów. Skuteczność algorytmów została sprawdzona przy wykorzystaniu stanowiska pomiarowego umożliwiającego wykonanie zdjęć obiektu testowego przesuwanego z rozdzielczością poniżej jednego mikrometra. Testy zaproponowanych rozwiązań potwierdziły ich skuteczność. Kolejnym krokiem, po testach opracowanego oprogramowania, było wyznaczenie rozkładu ciśnienia na płaskiej płycie poddanej strumieniowi sprężonego powietrza. Przedstawione procedury oraz wyniki mogą być użyteczne dla grup badawczych wdrażających technikę farb czułych na ciśnienie do pomiarów w tunelach aerodynamicznych oraz badań przepływów wewnętrznych.

Słowa kluczowe: farba czuła na ciśnienie, analiza obrazu, wypływ z dyszy 